For numbered affiliations see end of article.

Correspondence to: Z A Bhutta Zulfiqar.bhutta@aku.edu Cite this as: BMJ 2021;375:e067384 http://dx.doi.org/10.1136/BMJ-2021-067384 Published: 15 November 2021

\section{Conflict, extremism, resilience and peace in South Asia; can covid-19 provide a bridge for peace and rapprochement?}

\author{
Zulfiqar A Bhutta, ${ }^{1,2}$ Arun Mitra, ${ }^{3}$ Afsah Salman, ${ }^{4}$ Fawad Akbari, ${ }^{5}$ Suraya Dalil, ${ }^{6}$ Fyezah Jehan, ${ }^{7}$ \\ Mushtaque Chowdhury, ${ }^{8}$ Saroj Jayasinghe, ${ }^{9}$ Purnima Menon, ${ }^{10}$ Samiran Nundy, ${ }^{11}$ Firdausi Qadri, ${ }^{12}$ \\ Md Taufiqul Islam, ${ }^{12}$ Kul Gautam ${ }^{13}$
}

http://dx.doi.org/10.13039/501100006126

Hospital for Sick Children

South Asia, home to 1.97 billion people ( $25 \%$ of the world's population), is no stranger to conflict and confrontation. Longstanding border disputes (such as between India and China and the decades-old standoff between India and Pakistan), the forced displacement of Myanmar Muslims to Bangladesh, and the 2021 rise of the Taliban triggering a mass exodus of professionals and educated women from Afghanistan underscore the enormous volatility and unpredictability of the region. Climate change poses a further challenge, with the real risk of interstate "water wars." Indeed, South Asia now faces a range of threats, with real risks of these spilling over into interstate conflict.

The links between longstanding conflict, insecurity, and poverty are well recognised. ${ }^{23}$ Abject poverty, especially when associated with disparities, underlies many of the known conflicts worldwide, unsurprisingly given the drain conflict places on social sector spending. And although lack of social inclusion and ethnic inequalities have been shown to lead to domestic terrorism, ${ }^{4}$ economic inequalities and grievances are stronger drivers of rebellion, ${ }^{5}$ and are particularly relevant in South Asia. Despite robust economic growth and progress on many technological fronts, South Asia still has the world's largest concentrations of poverty, illiteracy, malnutrition, and preventable maternal and child deaths outside sub-Saharan Africa. ${ }^{6}$ Widespread poverty is closely intertwined with social disparities, marginalisation on the basis of an egregious caste system, and vast inequities that perpetuate disillusionment, grassroot rebellion, and further conflict.

We have previously described the disruptive effects of conflict and insecurity on health systems, with some long term consequences on maternal and child health outcomes. ${ }^{7}$ Conflict, insecurity, and uncertainty affect planning and stable investments in health systems, and the extreme distrust between India and Pakistan continues to jeopardise public health and social protection in South Asia. The two countries have fought three wars since independence in 1947, have hundreds of thousands of troops deployed on volatile borders, and dedicate $14-18 \%$ of their entire government budget to military spending, ${ }^{9}{ }^{10}$ leaving little for human development and social safety nets. For example, the decades long face-off of troops at the Siachen glacier continues to cost India and Pakistan over $\$ 600$ m annually, ${ }^{11}$ about the cost of the entire primary care and public health programme in 34 provinces of Afghanistan for 2021-23. ${ }^{12}$ These expenditures also pale in the face of the enormous cost of maintaining nuclear arsenals and delivery systems in India and Pakistan, ${ }^{13} \mathrm{a}$ travesty given that $22-28 \%$ of children in both countries don't receive routine early immunisations. ${ }^{14}$

The history of conflict and vast inequities meant the region was a sitting duck for an infectious disease outbreak that took full advantage of social vulnerability. The covid-19 pandemic has clearly exposed the extreme fragility of health systems, the limitations of emergency response capacity, inadequate early disease warning capabilities, and miniscule social support systems in the region. Consequently, South Asia has fared badly, with massive social and economic disruptions and the emergence of the delta variant leading to tremendous excess mortality across many countries in the region, including Sri Lanka, which had been less affected in the early phases of the pandemic (fig 1). ${ }^{1516}$ Education was interrupted for an estimated 434 million children, and numbers of teenage pregnancies rose by over 450 ooo as young girls were married after dropping out of school. ${ }^{17}$ 


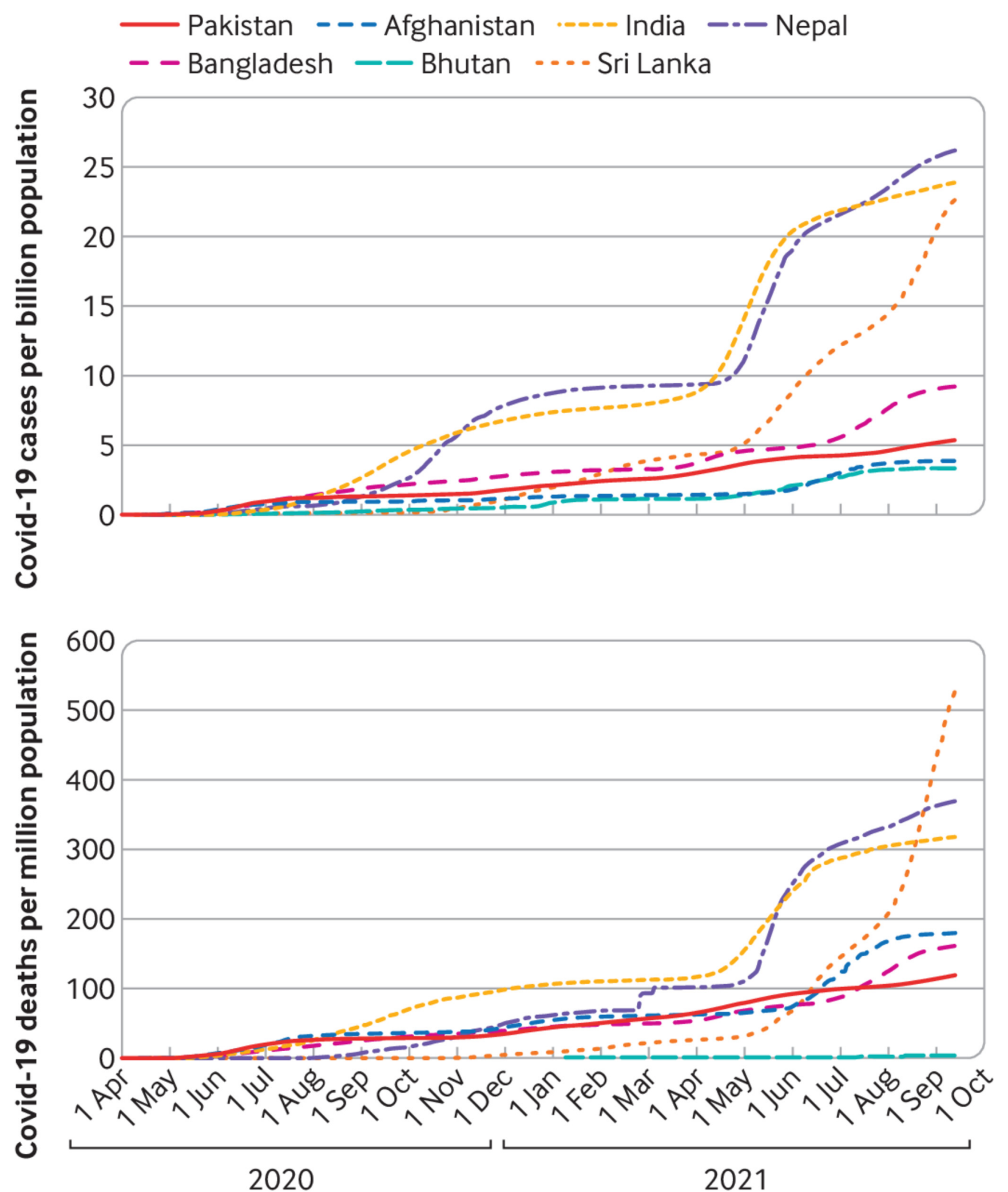

Fig 1| Trends in covid-19 cases/million population (top) and deaths/million population (bottom) in South Asia. April 2020 to October 2021

Peace in the region and improved relationships between South Asian countries could have mitigated the toll of covid-19. The pandemic now offers an opportunity and a compelling reason to put conflict aside in the interest of public health.

\section{Lack of common learning and exchanges}

Despite past exhortations for a regional approach to emerging infectious diseases, ${ }^{18}$ the pandemic has been a reality check for 
South Asia. There was negligible regional collaboration and information exchange, and no stable platform for joint action. An initial convening of the heads of states of countries in the South Asian Association for Regional Cooperation (SAARC) in March 2020 led to the creation of an extremely modest emergency covid-19 fund of around $\$ 11.5 \mathrm{~m}$, mainly based on voluntary contributions. ${ }^{19}$ However, little of this money has been disbursed, and tangible collaboration in surveillance, information exchange, or early warning of emerging risks from variants of concern has been negligible. No large collaborative international projects have been launched by science bodies and research centres in South Asia.

Although there were remarkable exemplars of resilience and stable national public health programmes such as the BRAC outreach workers ${ }^{20}-$ community health workers in Pakistan and India ${ }^{21}$-there were few common learning platforms specific to South Asia (despite the plethora of webinars with participants from the region) and no functional networks of public health institutions. Glaringly, unlike in other regions, there have been no data sharing exercises across South Asia related to covid-19 and vaccination coverage.

The capacity of the region to mount an emergency response to covid-19 partly depended on national and regional development of rapid diagnostic capacities; production of much needed personal protection equipment, oximeters, and ventilators; and a reliable oxygen production and supply chain across the region. Although India rapidly developed its own testing capacities, several South Asian countries spent a fortune importing expensive reagents and testing kits that could have been procured regionally at a fraction of the cost. ${ }^{22}$ The varying capacities within the region in vaccines and biological medicines could not have been starker; political differences and conflict pipped public health measures and international cooperation. India rapidly positioned itself to become the mainstay of the global supply chain for Covax vaccine distribution ${ }^{23}$ and launched regional vaccine donations to South Asian neighbours, explicitly excluding Pakistan. ${ }^{24}$ However, this vaccine diplomacy was also short lived as a rise in cases related to the delta variant led India to stop exports completely.

Collaboration, common learning, and shared experience could have improved other aspects of the pandemic response. For example, one of the serious harms of covid-19 mitigation strategies such as lockdowns has been their economic impact on people on low incomes, with social safety nets insufficient to meet the challenges. The first lockdown in India was associated with massive social upheaval and population displacement from cities to rural areas, ${ }^{25}$ and although this was followed by a massive ramp up and expanded reach of food and other safety nets, the effects on food security remain. ${ }^{26}$ Similar effects were noted in Bangladesh. ${ }^{27}$ In contrast, Pakistan rapidly executed a programme of emergency cash transfers, ${ }^{28}$ blunting much of the early economic shock and permitting the government to institute mitigation measures at scale. An early and free exchange of ideas and options across the region could have led to a much more coherent policy response and mutual learnings to the benefit of those on low incomes.

\section{Potential role of health diplomacy}

The ability of health related efforts to drive long term peace and stability has been questioned. ${ }^{29}$ However, such efforts have previously paused hostilities in Africa and Latin America to allow for humanitarian assistance and mass immunisations (such as for smallpox and polio)..$^{30}$ Public health imperatives have previously surmounted conflict in South Asia, including the massive outpouring of support and sympathy from the region during the Pakistan earthquake in $2005^{31}$ and recent responses from civil society in Pakistan in the wake of the covid-19 disaster in India. ${ }^{32}$

For their part, health professionals often already work in close collaboration with local, regional, and global civil society institutions and networks to promote peace, health, and wellbeing. Voices from the International Physicians for the Prevention of Nuclear War and International Campaign to Abolish Nuclear Weapons ${ }^{33}$ and others ${ }^{34}$ have been advocating for peace and de-escalation in the region for years. Public health and development professionals in the region must come together to strengthen learning and support regional peace and security as critical ingredients for South Asia's human, economic, and social development. Numerous examples exist of health experts from different countries mobilising to provide humanitarian assistance to neighbouring countries in times of crises, and they need to do the same in responding to covid-19. Improved technology now permits much easier intraregional interaction digitally.

\section{Tackling poverty and inequity}

Although the main goals of health diplomacy are to promote health by enhanced interaction and collaboration between states and civil society organisations and to improve health security and population health, an explicit focus on reducing poverty and inequities gives the exercise much greater legitimacy and appeal. Furthermore, progress towards peace and security cannot be made without tackling root causes of conflict such as poverty, corruption, and inequalities; ensuring application of the rule of law; respect for human rights; small arms control; and improved governance. Reducing inequities and social marginalisation could also help mitigate important root causes of obscurantism and militancy.

If there is one lesson from covid-19 across the world, it is that systemic inequities and disparities led to much of the avoidable excess mortality. As we advocate for restoration of peace, confidence building, and strengthening public health services in South Asia, a clear focus must be on reducing health disparities and reaching the unreached. This requires investment in human resources and infrastructure for primary healthcare and education, both of which have been seriously hampered by the current pandemic. Redirecting public policy and funds towards unmet social needs and a renewed battle against poverty, hunger, disease, and illiteracy would surely be the most important triumph for a region that boasts $25 \%$ of the world's population and one of the largest clustering of economically disadvantaged people, including in urban areas.

Calls for strengthening of primary care and human development investments in South Asia are not new and were the centrepiece of the landmark Bhore committee recommendations as far back as 1946.35 The unprecedented crisis created by covid-19 offers an opportunity to make gains on the inequities it laid bare. However, building back fairer after covid-19 will need a substantial reduction in military build-up and expenditure and a corresponding increase in expenditures on health and education across the region, which are very low presently (table 1). ${ }^{36-40}$ 
Table 1 | Social sector investments and covid-19 deaths per million population in South Asia and other global regions

\begin{tabular}{|c|c|c|c|c|c|c|c|c|c|c|c|c|c|c|c|c|c|c|}
\hline & \multicolumn{4}{|c|}{ Military expenditure 30} & \multicolumn{4}{|c|}{ Arms transfers ${ }^{30}$ (trend indicator values) } & \multicolumn{4}{|c|}{ Health expenditure 3132} & \multicolumn{4}{|c|}{ Education $^{32} 33$} & \multicolumn{2}{|c|}{$\begin{array}{c}\text { Covid-19 } \\
\text { deaths/million } \\
\text { population }\end{array}$} \\
\hline & \multicolumn{2}{|c|}{$\%$ of GDP } & \multicolumn{2}{|c|}{$\begin{array}{l}\% \text { of central } \\
\text { government } \\
\text { expenditure }\end{array}$} & \multicolumn{2}{|c|}{ Exports (\$m) } & \multicolumn{2}{|c|}{ Imports (\$m) } & \multicolumn{2}{|c|}{$\begin{array}{c}\text { Expenditure/capita } \\
\text { (current } \\
\text { international \$) }\end{array}$} & \multicolumn{2}{|c|}{$\%$ of GDP } & \multicolumn{2}{|c|}{$\begin{array}{c}\text { Expenditure per } \\
\text { student, primary (\% } \\
\text { of GDP per capita) }\end{array}$} & \multicolumn{2}{|c|}{$\begin{array}{l}\text { Total expenditure } \\
\text { (\% of GDP) }\end{array}$} & \multirow[t]{2}{*}{2020} & \multirow[t]{2}{*}{$2021^{*}$} \\
\hline & 2010 & 2020 & 2010 & 2020 & 2010 & 2020 & 2010 & 2020 & 2010 & 2018 & 2010 & 2018 & 2010 & 2018 & 2010 & $2018 / 2019$ & & \\
\hline Afgharistan & 1.9 & 1.4 & 9.4 & 4.5 & - & - & 377 & 277 & 45.0 & 49.8 & 8.6 & 9.4 & 12.0 & - & 3.5 & - & 54.9 & 127.1 \\
\hline Bangadesh & 1.3 & 1.3 & 11.2 & 9.3 & - & - & 36 & 46 & 20.8 & 41.9 & 2.5 & 2.3 & - & - & - & 1.3 & 45.4 & 121.7 \\
\hline Bhutan & - & - & - & - & - & - & - & - & 74.1 & 102.7 & 3.5 & 3.1 & 7.5 & - & 4.2 & 6.9 & 0 & 3.8 \\
\hline India & 2.9 & 2.9 & 9.9 & 9.1 & 5 & 151 & 2911 & 2799 & 45.1 & 72.8 & 3.3 & 3.5 & 7.5 & - & 3.4 & - & 106.9 & 218.7 \\
\hline Maldives & - & - & - & - & - & - & 5 & 3 & 600.6 & 973.5 & 8.5 & 9.4 & 15.2 & - & 4.1 & - & 88.3 & 353.2 \\
\hline Nepal & 1.6 & 1.4 & 8.3 & 4.8 & - & - & 3 & 36 & 30.0 & 57.9 & 5.0 & 5.8 & 11.1 & - & 3.6 & 5.1 & 62.5 & 319.5 \\
\hline Pakistan & 3.4 & 4.0 & 16.8 & 17.4 & 1 & 1 & 2205 & 759 & 25.3 & 42.9 & 2.6 & 3.2 & - & - & 2.3 & - & 45.2 & 80.8 \\
\hline $\begin{array}{l}\text { Sri } \\
\text { Lanka }\end{array}$ & 2.7 & 1.9 & 13.5 & 10.3 & - & - & 4 & 59 & 108.3 & 157.5 & 3.9 & 3.8 & 5.1 & 7.9 & 1.7 & 2.1 & 9.5 & 622.0 \\
\hline World & 2.5 & 2.4 & 6.7 & 6.1 & - & - & 25718 & 22400 & 914.2 & 1111.8 & 9.6 & 9.8 & 15.2 & - & 4.5 & - & 241.9 & 392.4 \\
\hline $\begin{array}{l}\text { East } \\
\text { Asia and } \\
\text { Pacific }\end{array}$ & 1.5 & 1.8 & 5.5 & 5.0 & - & 2287 & 6325 & 5848 & 478.3 & 721.9 & 6.3 & 6.7 & 12.4 & - & 3.6 & - & 19 & 110.8 \\
\hline $\begin{array}{l}\text { Europe } \\
\text { and } \\
\text { Central } \\
\text { Asia }\end{array}$ & 1.8 & 1.9 & 3.9 & 3.8 & 14334 & 10353 & 4612 & 2998 & 2192.8 & 2346.6 & 9.2 & 9.3 & 22.2 & - & 5.2 & - & 624 & 875.1 \\
\hline $\begin{array}{l}\text { Latin } \\
\text { America } \\
\text { and } \\
\text { Caribbean }\end{array}$ & 1.4 & 1.3 & 4.1 & 3.6 & - & 22 & 1600 & 951 & 654.9 & 666.9 & 7.3 & 8.0 & 13.9 & - & 4.7 & - & 853.54 & 1430.8 \\
\hline $\begin{array}{l}\text { Middle } \\
\text { East and } \\
\text { North } \\
\text { Africa }\end{array}$ & 4.7 & 5.2 & 15.5 & 16.5 & - & - & 5279 & 6466 & 341.5 & 520.9 & 4.7 & 6.0 & - & - & - & - & 240.6 & 338.2 \\
\hline $\begin{array}{l}\text { North } \\
\text { America }\end{array}$ & 4.6 & 3.6 & 11.2 & 2.5 & 8299 & 9572 & 1319 & 894 & 7644.7 & $\begin{array}{c}10 \\
050.3 \\
\end{array}$ & 15.8 & 16.4 & 22.1 & - & 5.4 & - & 990.7 & 1069.2 \\
\hline $\begin{array}{l}\text { South } \\
\text { Asia }\end{array}$ & 2.8 & 2.8 & 10.6 & 9.8 & 5 & 151 & 5538 & 3834 & 41.4 & 67.2 & 3.23 & 3.5 & 9.3 & - & 3.4 & - & 91.1 & 197.8 \\
\hline $\begin{array}{l}\text { Substaran } \\
\text { Africa }\end{array}$ & 1.3 & 1.1 & 5 & 4.7 & - & - & 1045 & - & 83.7 & 83.3 & 5.2 & 5.1 & 10.4 & - & 3.5 & 4.3 & 60.44 & 161.4 \\
\hline
\end{tabular}

*Up to 23 October.

\section{Looking forward-fairly, sustainably, and peacefully}

What practical steps can help the post-covid rebuilding process, rebuild confidence in collaboration, and promote peace? We propose several actions that are not resource intensive but could foster peace in the interest of public health and help in the recovery from the pandemic.

\section{Empowering women to support public health measures and broker peace}

South Asia must tackle widespread gender inequality in its largely patriarchal societies and support the role of women as peace makers. Women have often been central to conflict resolution and had key leadership roles in the response to covid-19 in South Asia, including as frontline health workers..$^{41}$ In India, K K Shailaja, Kerala's former minister for health and family welfare, was praised for her leadership in the covid-19 crisis, leading to calls for women leaders to have a greater role in national politics. ${ }^{42}$ In Nepal, Tika Dahal led a programme for the support of disabled people during the pandemic, 43 and Sania Nishtar spearheaded the highly praised safety net programme for women in Pakistan. ${ }^{44}$

We call on many women leaders in public health, gender studies, and development in South Asia to take an active role in rebuilding from the current crisis and perhaps to play a part in brokering peace. We also call on political leaders to acknowledge the substantial challenges that women leaders face and to remove the political, institutional, and societal barriers that exist.

\section{Revitalise SAARC and create key partnerships}

SAARC was founded in December 1985 to promote peace and prosperity through regional collaboration, working towards a common market and economic integration. It has remained ineffective in various areas, often because of disagreements between India and Pakistan. India has begun to preferentially engage with other regional groupings such as the Bay of Bengal Initiative for Multi-Sectoral Technical and Economic Cooperation, ${ }^{45}$ potentially undermining the relevance of SAARC. Shifting the focus of SAARC towards shared concerns for human development and health security, catalysing public health collaboration through a substantially enhanced SAARC Development Fund, ${ }^{46}$ with an explicit focus on projects to rebuild health and education systems after covid-19, might revive its relevance and impact.

A critical prerequisite for this would be the restoration of confidence in the institution and a move towards promotion of peace through conflict resolution. The fact that the secretariat for both the Unicef 
regional office for South Asia and SAARC are located in Kathmandu should make joint planning easier, and we challenge both agencies to work closely together for relevant health and education activities.

\section{Create an independent commission for health, peace, and development in South Asia}

We propose the creation of an independent commission of representatives from academia, research, and science bodies and civil society organisations to come together to deliberate on mechanisms for promoting health, peace, and development in South Asia. There is precedent in the form of independent civic society and citizen-led dialogues, the so called track 2 diplomacy efforts to break the logjam of inaction and advocate for increased collaboration and investments in social sectors. 47

The BMJ South Asia is one such initiative that has provided a platform for regional overviews and international scholarly outputs on issues related to health. It could be the host for an initiative focused on identifying regional priority actions for health and social determinants of health within a defined time frame, with clear deliverables and outcome measures. A common mission could also be promoting greater collaboration in development of vaccines and biological medicines in the region, an area where centralisation of capacity has been shown to have serious limitations.

\section{Promote people to people contacts, cultural, sports, and educational activities}

South Asian peoples are rooted in ancient civilisations and a deep and resilient culture. Despite diversity of faiths, ethnicities, and geographies, they have largely lived together peacefully. In recent decades, however, exchanges between different groups, especially the youth in the region, have been minimal. Shrill, jingoistic media and unwanted acrimony in cultural and sports events have further alienated civic society. As we emerge from the pandemic, we need to promote greater exchanges between peoples of the region. Removing arcane and divisive visa arrangements would help promote peace and many of the actions outlined above.

Mistrust and security challenges since independence from colonial rule have meant that too many South Asians live in fear, poverty, and ill health, with uncertain futures. Although the covid-19 pandemic has substantially set back economic progress and human development in the region, it also offers an opportunity to jumpstart change in building back a fair and secure future for our children. Now, more than ever, we need to join hands to support our shared humanity and shape a new future for generations to come.

\section{AUTHOR AFFILIATIONS}

\footnotetext{
Centre for Global Child Health, Hospital for Sick Children, Toronto, Canada

Institute for Global Health and Development, Aga Khan University, South-central Asia East Africa, and UK

Indian Doctors for Peace \& Development, Ludhiana, Punjab, India

Trust for Vaccines and Immunizations, Karachi, Pakistan

Aga Khan Foundation Canada, Ottawa, Canada

Special Programme on Primary Health Care, World Health Organization, Geneva

Department of Paediatrics and Child Health, Aga Khan University, Karachi, Pakistan

BRAC University, Dhaka, Bangladesh

University of Colombo, Columbo, Sri Lanka
}

10 International Food Policy Research Institute, New Dehli, India

Department of Surgical Gastroenterology and Liver Transplantation, Sir Ganga Ram Hospital, New Delhi, India

Enteric and Respiratory Infections, Infectious Diseases Division, International Centre for Diarrhoeal Disease Research, Bangladesh, Dhaka, Bangladesh

Unicef, New York, USA

Competing interests: We have read and understood BMJ policy on declaration of interests and have no relevant interests to declare.

Contributors and sources: $Z A B$ is a paediatrician and the founding director of the Institute for Global Health and Development and Centre of Excellence in Women and Child Health and is a leading voice for integrated maternal, newborn, child and adolescent health. AM is a consultant ear, nose, and throat surgeon in Ludhiana in Punjab state of India and co-president of International Physicians for the Prevention of Nuclear War. AS is a medical graduate involved in research syntheses and primary care research in Pakistan and a strong advocate for gender equity and girls' empowerment. FA is an Afghan-Canadian who oversees public health and other multisectoral programmes in South-Central Asia. His research and teaching focuses on fragility, global health and gender equality. SD is the former minister of health of the government of Afghanistan. FJ is an infectious diseases specialist whose research includes innovative approaches in health and nutrition for poor women in community settings. MC is an adviser of the BRAC University James P Grant School of Public Health in Dhaka, Bangladesh and professor of population and family health at Columbia University in New York. S) is a physician from Sri Lanka who has written widely on systems science, urban health, and issues related to the covid pandemic. PM studies nutrition in South Asia, including research on improving the quality, scale and impact of community-based and health systems-based nutrition actions, and on tackling gender, poverty and other prominent social determinants of nutrition in the region. SN has edited five Indian medical journals, including the Indian Journal of Medical Ethics. FQ is a public health expert with a focus on common childhood diseases and vaccines. MTI is involved in different epidemiological studies on enteric diseases and control measures including oral cholera vaccine in several field trials. KG's role at Unicef involved promoting the concept of health as a bridge to peace globally, especially in Central America. ZAB wrote the first draft of the paper with contributions from co-authors. All authors reviewed and provided inputs and approved the final version for submission. ZAB is the guarantor.

Provenance and peer review: Not commissioned; externally peer reviewed.

We thank Muhammad Islam and Pretty Rattan for generating the data for the figure and table, and Daina Als for administrative support. This work was supported by core funding from the Institute for Global Health and Development, the Aga Khan University, and the Centre for Global Child Health, The Hospital for Sick Children, Toronto, Canada.

1 Bhalla N. Thirsty South Asia's river rifts threaten “water wars."Reuters 2012. https://www.reuters.com/article/us-water-southasia-idUSBRE86M0C820120723

2 Brentlinger PE, Hernán MA. Armed conflict and poverty in Central America: the convergence of epidemiology and human rights advocacy. Epidemiology 2007;18:673-7. doi: 10.1097/EDE.0b013e3181570c24. pmid: 18049183

3 Fürst T, Tschannen AB, Raso G, etal. Effect of an armed conflict on relative socioeconomic position of rural households: case study from western Côte d'Ivoire. Emerg Themes Epidemiol 2010;7:6. doi: 10.1186/1742-7622-7-6. pmid: 20807398

4 Fleming CM, Manning M, Pham HT, Vorsina M. Ethnic economic inequality and fatalities from terrorism. J Interpers Violence 2020:886260520976226.doi: 10.1177/0886260520976226. pmid: 33319608

5 Collier P, Hoeffler A. Greed and grievance in civil war. Oxf Econ Pap 2004;56:563-95doi: 10.1093/oep/gpf064.

6 Akseer N, Kamali M, Arifeen SE, etal. Progress in maternal and child health: how has South Asia fared?BM/2017;357:j1608. doi: 10.1136/bmj.j1608. pmid: 28400481

7 Wagner Z, Heft-Neal S, Wise PH, etal. Women and children living in areas of armed conflict in Africa: a geospatial analysis of mortality and orphanhood. Lancet Glob Health 2019;7:e1622-31. doi: 10.1016/S2214-109X(19)30407-3. pmid: 31669039

8 Bendavid E, Boerma T, Akseer N, etalBRANCH Consortium Steering Committee. The effects of armed conflict on the health of women and children. Lancet 2021;397:522-32. doi: 10.1016/S0140-6736(21)00131-8. pmid: 33503456

9 The World Bank. World development indicators.http://wdi.worldbank.org/table/5.7\#

10 Da Silva DL, Tian N, Marksteiner A. Trends in world military expenditure 2020. SIPRI fact sheet. Apr 2021. https://sipri.org/sites/default/files/2021-04/fs_2104_milex_0.pdf

11 Siachen: all you should know about the world's costliest battlefield. Economic Times. 2019 Nov 20. https://economictimes.indiatimes.com/news/defence/siachen-all-you-should-know-aboutthe-worlds-costliest-battlefield/articleshow/72142137.cms?from=mdr

12 World Bank. Afghanistan Sehatmandi project. https://projects.worldbank.org/en/projects-operations/project-detail/P160615

13 Lavoy P. The costs of nuclear weapons in South Asia. 2002. https://www.researchgate.net/publication/304596012_The_Costs_of_Nuclear_Weapons_in_South_Asia

14 Hasman A, Noble DJ. Childhood immunisation in South Asia-overcoming the hurdles to progress Perspect Public Health 2016;136:273-7. doi: 10.1177/1757913916658633. pmid: 27528641 
15 Johns Hopkins University. Our world in data. https://ourworldindata.org/covid-cases. Accessed 23 Oct 2021.

16 Bhutta ZA, Siddiqi S, Hafeez A, etal. Beyond the numbers: understanding the diversity of covid-19 epidemiology and response in South Asia. BMJ 2021;373:n1544. doi: 10.1136/bmj.n1544. pmid: 34172460

17 Unicef, WHO, UNFPA, SickKids Centre for Global Child Health. Direct and indirect effects of the covid-19 pandemic and response in South Asia. 2021. https://www.unicef.org/rosa/reports/directand-indirect-effects-covid-19-pandemic-and-response-south-asia

18 Laxminarayan R, Kakkar M, Horby P, Malavige GN, Basnyat B. Emerging and re-emerging infectious disease threats in South Asia: status, vulnerability, preparedness, and outlook. BMJ 2017;357:j1447. doi: 10.1136/bmj.j1447. pmid: 28400386

19 SAARC Disaster Management Center. COVID-19 Emergency Fund. http://covid19-sdmc.org/covid19emergency-fund

20 Jolly SP, Chowdhury TR, Rahman M, Alam A, Afsana K. Prevention of social exclusion and role of antenatal care by BRAC community health workers in improving safe motherhood and neonatal care in urban slums of Bangladesh. PLoS One 2020;15:e0235340. doi: 10.1371/journal.pone.0235340. pmid: 32639998

21 Bhutta ZA, Bang A, Afsana K, Gyawali B, Mirzazada S, Jayatissa R. Rethinking community based strategies to tackle health inequities in South Asia. BMJ2018;363:k4884. doi: 10.1136/bmj.k4884. pmid: 30498009

22 Bhutta ZA, Sultan F, Ikram A, Haider A, Hafeez A, Islam M. Balancing science and public policy in Pakistan's COVID-19 response. East Mediterr Health /2021;27:798-805. doi: 10.26719/emhj.21.016. pmid: 34486716

23 Jerving S. India crisis puts Covax 150 million doses behind schedule. 2021. https://www.devex.com/news/india-crisis-puts-covax-150-million-doses-behind-schedule-99860

24 Bose S. Observer Research Foundation. The dynamics of vaccine diplomacy in India's neighborhood. ORF special report 145. 2021. https://www.orfonline.org/research/the-dynamics of-vaccine-diplomacy-in-indias-neighbourhood/

25 Mohan M, Mishra S. India's response to the covid-19 pandemic: a frontal assault on the "historically dispossessed". Int J Health Serv 2021:51:107-14. doi: 10.1177/0020731420968438. pmid: 33092455

26 Bhargava R, Bhargava M. World Economic Forum. Covid-19 is creating a hunger pandemic in India-here's an opportunity to break the cycle. 2021. https://www.weforum.org/agenda/2021/06/covid-19-pandemic-hunger-catastrophe-india-poverty-food-insecurity-relief/

27 Mottaleb KA, Mainuddin M, Sonobe T. COVID-19 induced economic loss and ensuring food security for vulnerable groups: Policy implications from Bangladesh. PLoS One 2020;15:e0240709. doi: 10.1371/journal.pone.0240709. pmid: 33064771

28 Democracy Reporting International. Covid-19 policy brief series. Evaluating Ehsaas emergency cash transfer program-successes, oversights and possibilities. 2020.

https://www.cgdev.org/publication/womens-access-cash-transfers-light-covid-19

29 Rushton S, McInnes C. The UK, health and peace-building: the mysterious disappearance of health as a bridge for peace. Med Confl Surviv 2006;22:94-109. doi: 10.1080/13623690600620940. pmid: 16749475

30 de Quadros CA, Epstein DPan American Health Organization. Health as a bridge for peace: PAHO's experience. Lancet 2002;360(Suppl):s25-6. doi: 10.1016/S0140-6736(02)11808-3. pmid: 12504491

31 Mancuso JD, Price O, West DF. The emerging role of preventive medicine in health diplomacy after the 2005 earthquake in Pakistan. Mil Med 2008;173:113-8. doi: 10.7205/MILMED.173.2.113. pmid: 18333485

32 Pandey G. India Covid-19: Al shows Pakistani Twitter prayed for India. BBC News 2021 Jul 2.https://www.bbc.com/news/world-asia-india-57683808

33 Ur Rahman S, Mudur G. Doctors in India and Pakistan campaign against nuclear war. BMJ 2002;324:1412. doi: 10.1136/bmj.324.7351.1412/b.

34 Bhutta ZA, Nundy S. Thinking the unthinkable!BMJ 2002;324:1405-6. doi: 10.1136/bmj.324.7351.1405. pmid: 12065248

35 Health Service and Development CommitteeBhore Committee. 1946. https://www.nhp.gov.in/bhore-committee-1946_pg

36 Bloch C. Social spending in South Asia: an overview of government expenditure on health, education and social assistance. Research Report No 44. 2020. https://www.unicef.org/rosa/media/10016/file/Social\%20spending\%20in\%20South\%20Asia.pdf

37 Stockholm International Peace Research Institute (SIPRI) Yearbook: Armaments, Disarmament and International Security. https://www.sipri.org/yearbook

38 World Health Organization Global Health Expenditure database. https://apps.who.int/nha/database

39 World Bank Statistics. http://wdi.worldbank.org/table/5.7\#; https://data.worldbank.org/indicator/SE.XPD.PRIM.PC.ZS

40 UNESCO Institute for Statistics. Government expenditure on education, total (\% of GDP). uis.unesco.org

41 Rabinowitz LG, Rabinowitz DG. Women on the frontline: a changed workforce and the fight against covid-19. Acad Med 2021;96:808-12. doi: 10.1097/ACM.0000000000004011. pmid: 34031302

42 Spinney L. How KK Shailaja and her "COVID-19 brigade" won a victory against the virus? Guardian 2020 Dec 22. https://www.theguardian.com/lifeandstyle/2020/dec/22/how-kk-shailaja-and-hercovid-brigade-won-a-victory-against-the-virus
43 Amnesty International. Women in the frontlines: women leaders responding to COVID-19 in South Asia. 2021. https://www.amnesty.org/en/latest/news/2021/03/women-leaders-in-south-asiaresponding-to-the-pandemic/

44 Delivery Associates. The Ehsaas programme report. 2020. https:/www.deliveryassociates.com/media/ehsaas-programme-report

45 Wikipedia. Bay of Bengal Initiative for Multisectoral Technical \& Economic Cooperation. https://en.wikipedia.org/wiki/Bay_of_Bengal_Initiative_for_Multi-Sectoral_Technical_and_Economic_Cooperation

46 SAARC Development Fund Secretariat. http://www.sdfsec.org/

47 Mapendere J. Track one and a half diplomacy and complementarity of tracks. Culture of Peace 2001;2:66-81. https://peacemaker.un.org/sites/peacemaker.un.org/files/TrackOneandaHalfDiplomacy_Mapendere.pdf

This is an Open Access article distributed in accordance with the Creative Commons Attribution Non Commercial (CC BY-NC 4.0) license, which permits others to distribute, remix, adapt, build upon this work non-commercially, and license their derivative works on different terms, provided the original work is properly cited and the use is non-commercial. See: http://creativecommons.org/licenses/bync/4.0/. 